\title{
Pengaruh Penambahan Massa Cangkang Kerang Darah (Anadara granosa) Teraktivasi pada Peningkatan Kualitas Air Sumur Bor \\ Rahimawatia, Nurhasanaha, Mega Nurhanisa ${ }^{a *}$
}

aProgram Studi Fisika, FMIPA Universitas Tanjungpura

*Email : meganurhanisa@physics.untan.ac.id

\begin{abstract}
Abstrak
Telah dilakukan penelitian tentang upaya meningkatkan kualitas air sumur bor. Penelitian ini memanfaatkan limbah cangkang kerang darah (Anadara granosa) sebagai bahan adsorben. Cangkang kerang darah dihaluskan dengan ukuran 150 mesh, kemudian diaktivasi fisika, kimia, dan fisika-kimia. Variasi massa yang digunakan yaitu 2 gram, 4 gram, 6 gram, 8 gram, dan 10 gram teraktivasi fisika, 10 gram teraktivasi kimia, dan 10 gram teraktivasi fisika-kimia. Hasil pengujian air sumur bor sebelum dan sesudah dilakukan penambahan serbuk cangkang kerang darah yang teraktivasi mengalami perubahan. Pada adsorben teraktivasi fisika dengan massa 10 gram diperoleh nilai pH 6,84, TDS sebesar 1529 mg/L, warna pada skala 684 Pt.Co, kekeruhan 144 NTU, dan kandungan Fe sebesar 0,82 mg/L. Dari hasil pengujian air sumur bor setelah dilakukan penambahan adsorben cangkang kerang darah teraktivasi kimia, diperoleh nilai pH 7,11, TDS sebesar 1776 mg/L, warna pada skala 406 Pt.Co, kekeruhan 107 NTU, dan kandungan Fe sebesar 1,49 mg/L. Sedangkan hasil pengujian air sumur bor pada adsorben teraktivasi fisika-kimia yaitu pH 11,83, TDS sebesar 1546 mg/L, warna pada skala 218 Pt.Co, kekeruhan 51,3 NTU, dan kandungan Fe sebesar 0,12 mg/L. Berdasarkan hasil yang didapatkan ada beberapa parameter yang tidak memenuhi standar baku yang telah ditetapkan Menteri Kesehatan Republik Indonesia Nomor 32 Tahun 2017, sehingga cangkang kerang tidak efektif digunakan untuk meningkatkan kualitas air sumur bor.
\end{abstract}

Kata Kunci : Air Sumur Bor, Aktivasi, Kerang Darah

\section{Latar Belakang}

Air merupakan suatu unsur yang sangat penting bagi kelangsungan hidup manusia. Oleh karena itu, air harus dalam kondisi yang bersih dan jernih sehingga aman digunakan. Air bersih adalah air yang digunakan untuk keperluan sehari-hari, kualitasnya memenuhi syarat kesehatan dan dapat diminum apabila telah dimasak. Syarat kesehatan tersebut yaitu harus memenuhi syarat secara fisik, kimia, radioaktivitas, dan mikrobiologi. Syarat dan pengawasan kualitas air telah diatur dalam Peraturan Menteri Kesehatan Nomor:416/MEN.KES/PER/IX/1990.

Kebutuhan air bersih meningkat tiap harinya, oleh karena itu perlu dilakukan proses peningkatan kualitas air untuk memenuhi pasokan air bersih. Proses penjernihan air dapat dilakukan dengan cara filtrasi, sedimentasi, absorpsi dan adsorpsi [1]. Pengolahan air bersih telah dilakukan menggunakan metode filtrasi dengan karbon aktif $[2,3]$, metode sedimentasi [4], dan metode fotodegradasi [5].

Air sumur bor digunakan sebagian masyarakat Pontianak dalam memenuhi kebutuhan air untuk keperluan sehari-hari. Air sumur bor di Pontianak pada umumnya memiliki ciri-ciri yaitu berwarna kuning kemerahan, berbau karat besi, rasanya payau, keruh, dan terdapat minyak di atas permukaan air.
Berdasarkan penelitian Manurung, kandungan Fe air sumur bor di Jl. Ampera, Pontianak provinsi Kalimantan Barat sebesar 13, 77 mg/L, pH 5,63 dan TDS 1875 mg/L [6]. Dari hasil yang diperoleh, air sumur bor tidak memenuhi baku mutu air dalam Peraturan Kementerian Kesehatan Republik Indonesia Nomor 32 tahun 2017. Air sumur yang di dalamnya terlarut Fe jika digunakan terus menerus dapat mengganggu kesehatan [3]. Oleh karena itu, perlu adanya solusi alternatif untuk meningkatkan kualitas air sumur bor tersebut.

Cangkang kerang darah dapat digunakan sebagai bahan adsorben karena mengandung kalsium karbonat $\left(\mathrm{CaCO}_{3}\right) \cdot \mathrm{CaCO}_{3}$ pada kerang mempunyai pori-pori di permukaan cangkangnya sehingga dapat menyerap atau mengadsorpsi logam berat [7]. Penelitian sebelumnya telah memanfaatkan cangkang kerang untuk menyerap logam berat seperti $\mathrm{Pb}$, $\mathrm{Cu}$, dan $\mathrm{Zn}$ [8], serta timah putih [9], dan Cu (II) [10] ke dalam pori-pori tersebut.

Kerang darah banyak terdapat di daerahdaerah sekitar Pontianak. Berdasarkan data dari Direktorat Jenderal Perikanan Tangkapan Indonesia 2012, jumlah kerang darah setiap tahunnya mencapai 48,994 ton. Jumlah kerang darah yang banyak ini dapat menimbulkan limbah cangkang kerang. Limbah cangkang kerang tersebut selain dibuang, juga dapat 
digunakan sebagai kerajinan tangan seperti hiasan dinding dan campuran pakan ternak [11].

Penelitian ini memanfaatkan cangkang kerang darah (Anadara granosa) yang telah diaktifkan melalui proses aktivasi fisika, aktivasi kimia, dan aktivasi fisika-kimia untuk meningkatkan kualitas air. Proses pengaktifan cangkang kerang sama dengan proses pembuatan karbon aktif, yang bertujuan untuk memperluas permukaan pada adsorben [3]. Karbon aktif dari cangkang kerang ini digunakan untuk mengadsorpsi TDS, warna, kekeruhan, $\mathrm{pH}$, dan Fe.

\section{Metodologi}

\subsection{Alat dan Bahan}

Alat yang digunakan dalam penelitian ini seperti furnace, timbangan, ayakan, aluminium foil, hummer mill, wrapping plastic, palu, mortar dan kertas saring. Bahan yang digunakan dalam penelitian ini yaitu cangkang kerang darah, air sumur bor, aquades dan asam sulfat $\left(\mathrm{H}_{2} \mathrm{SO}_{4}\right)$.

\subsection{Pembuatan Sampel Serbuk Cangkang Kerang dan Proses Aktivasi}

Sampel yang digunakan yaitu limbah cangkang kerang darah yang dikumpulkan dari masyarakat setempat. Cangkang kerang darah tersebut dibersihkan dari lumpur dan dikeringkan dengan cara dijemur di bawah panas terik matahari sampai kadar air pada sampel berkurang. Sampel yang telah kering dihancurkan menggunakan palu dengan ukuran 1 - $2 \mathrm{~cm}$ dan dihaluskan menggunakan hummer mill, kemudian ditumbuk dan diayak dengan ayakan 150 mesh. Cangkang kerang yang telah menjadi serbuk, kemudian diaktivasi secara fisika, kimia, dan fisika-kimia.

Aktivasi serbuk cangkang kerang dilakukan menggunakan furnace. Cangkang kerang yang diaktivasi fisika dibakar pada suhu $500^{\circ} \mathrm{C}$ selama 4 jam. Aktivasi kimia dilakukan setelah aktivasi fisika yaitu dengan merendam cangkang kerang menggunakan $\mathrm{H}_{2} \mathrm{SO}_{4}$ selama 24 jam, kemudian dikeringkan pada suhu $105^{\circ} \mathrm{C}$ selama 3 jam. Aktivasi fisika-kimia dilakukan setelah aktivasi kimia dan dibakar pada suhu $900^{\circ} \mathrm{C}$ selama 2 jam.

Adsorpsi menggunakan adsorben cangkang kerang darah dengan variasi massa 2 gram, 4 gram, 6 gram, 8 gram, dan 10 gram untuk aktivasi fisika. Serta 10 gram untuk aktivasi kimia dan fisika-kimia. Langkah-langkah pengujian adsorben dilakukan dengan menyediakan wadah-wadah yang telah diisi serbuk cangkang kerang dengan masing-masing variasi massa yang telah ditentukan. Tiap wadah tersebut ditambahkan air sumur bor sebanyak $1 \mathrm{~L}$, selanjutnya diaduk sampai merata dan didiamkan selama 6 jam.

\subsection{Pengujian Air Sumur Bor}

Pengujian sampel air sumur bor dilakukan dalam dua tahap. Pertama, yaitu pengujian sebelum diberi perlakuan. Pengujian kedua yaitu setelah diberi perlakuan aktivasi fisika, kimia serta fisika-kimia. Parameter pengujian meliputi parameter $\mathrm{pH}$, TDS, warna, kekeruhan, dan Fe. Hasil uji yang didapatkan kemudian digunakan untuk menentukan efektivitas adsorben dengan persamaan:

$$
\eta=\frac{A-B}{A} \times 100 \%
$$

$\eta$ adalah efektivitas, $A$ dan B masing-masing adalah parameter uji sebelum dan setelah perlakuan. Setelah dilakukan pengujian pada sampel sebelum dan sesudah penambahan adsorben, hasil yang diperoleh kemudian dibandingkan dengan standar baku mutu air pada Tabel 1.

Tabel 1. Parameter fisik dan kimia dalam standar baku mutu kesehatan lingkungan pada media air untuk keperluan higiene sanitasi

\begin{tabular}{lll}
\hline Parameter Wajib & Unit & $\begin{array}{l}\text { Standar } \\
\text { Baku Mutu }\end{array}$ \\
\hline $\mathrm{pH}$ & $\mathrm{mg} / \mathrm{L}$ & $6,5-8,5$ \\
Besi & $\mathrm{NTU}$ & 25 \\
Kekeruhan & $\mathrm{TCU}$ & 50 \\
Warna & $\mathrm{mg} / \mathrm{L}$ & 1000 \\
$\begin{array}{l}\text { Zat padat terlarut } \\
(\text { Total Dissolved Solid })\end{array}$ & & \\
\hline
\end{tabular}

Sumber: Peraturan Menteri Kesehatan Republik Indonesia Nomor 32 Tahun 2017 [12]

\section{Hasil dan Pembahasan}

\subsection{Serbuk Cangkang Kerang}

Gambar 1 merupakan butiran-butiran cangkang kerang darah yang telah digiling menggunakan hummer mill berukuran 80-100 mesh dan berwarna putih. Gambar 2 merupakan cangkang kerang yang telah ditumbuk menggunakan mortar dan diayak dengan ayakan 150 mesh. Dapat dilihat strukturnya lebih halus dibandingkan dengan sebelum ditumbuk. 


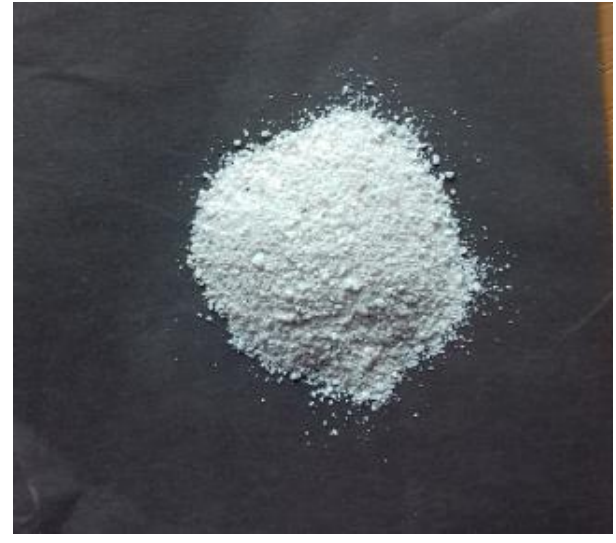

Gambar 1. Cangkang kerang yang telah digiling menggunakan Hummer Mill

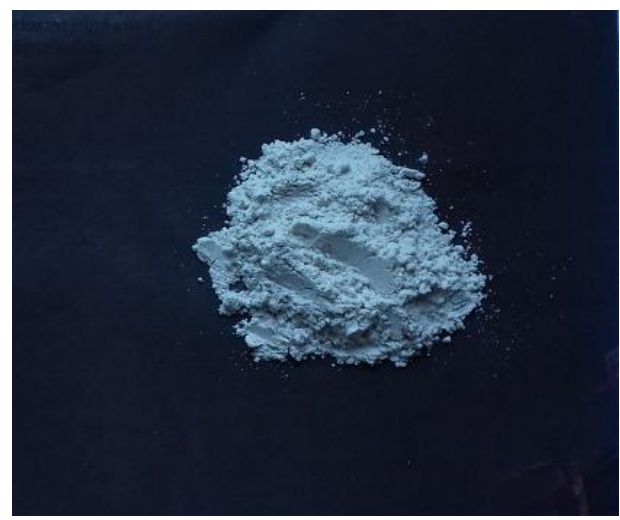

Gambar 2. Cangkang kerang yang telah ditumbuk dan diayak dengan ayakan 150 mesh.

a. Aktivasi Fisika

Aktivasi fisika dilakukan untuk menghilangkan kadar air yang masih terkandung dalam cangkang kerang dan membuka pori-pori pada cangkang kerang. Gambar 3 merupakan hasil serbuk cangkang kerang yang telah diaktivasi fisika pada suhu $500^{\circ} \mathrm{C}$ selama 4 jam.



Gambar 3. Serbuk cangkang kerang yang teraktivasi fisika
Pada proses aktivasi fisika, terjadi reaksi kimia seperti pada Persamaan 2 berikut:

$$
\mathrm{CaCO}_{3} \rightarrow \mathrm{CaO}+\mathrm{CO}_{2}
$$

Pada proses aktivasi fisika, $\mathrm{CaCO}_{3}$ pada kerang darah berubah menjadi $\mathrm{CaO}$ yang membawa sifat basa. Perubahan fisik yang dialami serbuk cangkang kerang terjadi karena selama proses aktivasi fisika terjadi pelepasan karbon dioksida $\mathrm{CO}_{2}$ pada karbon [13]

\section{b. Aktivasi Kimia}

Aktivasi kimia dilakukan dengan menambahkan bahan kimia berupa asam sulfat $\left(\mathrm{H}_{2} \mathrm{SO}_{4}\right)$ pada adsorben yang telah diaktivasi fisika, kemudian direndam selama 24 jam. Hasil rendaman tersebut dicuci sampai $\mathrm{pH}$ netral dan dikeringkan pada suhu $105^{\circ} \mathrm{C}$ selama 3 jam [3]. Perubahan fisik yang dialami serbuk cangkang kerang selama proses aktivasi kimia dikarenakan pada saat proses perendaman terjadi reaksi kimia, seperti pada Persamaan 3:

$$
\mathrm{CaO}+\mathrm{H}_{2} \mathrm{SO}_{4} \rightarrow \mathrm{CaO}+\mathrm{SO}_{3}+\mathrm{H}_{2} \mathrm{O}
$$

Persamaan 3 merupakan reaksi antara $\mathrm{CaO}$ dan $\mathrm{H}_{2} \mathrm{SO}_{4} . \quad \mathrm{H}_{2} \mathrm{O}$ merupakan air yang menutupi gugus aktif dan pori karbon sehingga mengurangi kapasitas adsorpsi karbon aktif. Gambar 4 merupakan serbuk cangkang kerang yang telah diaktivasi kimia. Warna pada serbuk cangkang kerang sebelum dan sesudah diaktivasi tidak mengalami banyak perubahan. Warna serbuk cangkang kerang menjadi lebih putih dibandingkan dengan sebelum diaktivasi kimia. $\mathrm{CaO}$ membuat warna cangkang kerang menjadi lebih putih [13].

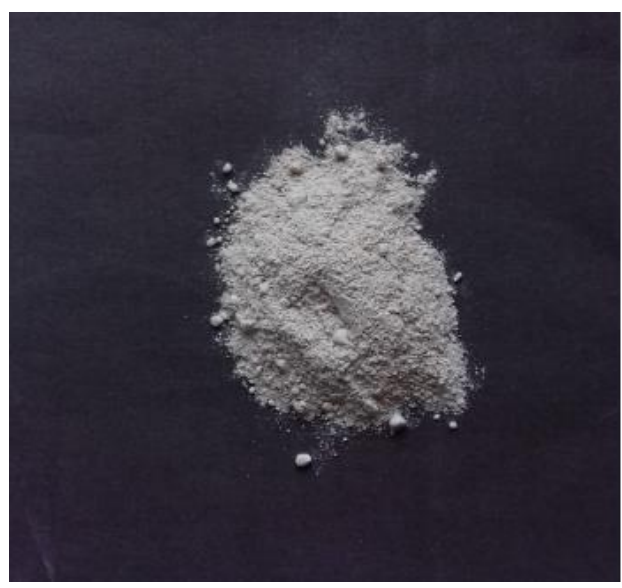

Gambar 4. Serbuk cangkang kerang yang teraktivasi kimia

c. Aktivasi Fisika-kimia

Karbon aktif yang telah diaktivasi kimia, diaktivasi lagi secara fisika yaitu dibakar 
menggunakan furnace pada suhu $900^{\circ} \mathrm{C}$ selama 2 jam. Persamaan 4 merupakan reaksi kimia selama proses aktivasi fisika-kimia berlangsung.

$$
\mathrm{CaSO}_{4}+\mathrm{H}_{2} \mathrm{O} \rightarrow \mathrm{CaSO}_{3}(\mathrm{OH})_{2}
$$

$\mathrm{CaSO}_{4}$ merupakan garam yang terbentuk saat proses aktivasi kimia. Ketika $\mathrm{CaSO}_{4}$ dibakar akan mengalami reaksi kimia, sehingga garam tersebut menjadi $\mathrm{CaSO}_{3}(\mathrm{OH})_{2}$ yang membawa sifat basa kuat. Gambar 5 merupakan serbuk cangkang kerang yang telah diaktivasi fisikakimia. Warna pada serbuk cangkang kerang sebelum dan sesudah diaktivasi tidak mengalami banyak perubahan. Warna cangkang kerang tersebut menjadi lebih putih dan bersih dibandingkan dengan sebelum diaktivasi, baik aktivasi fisika maupun aktivasi kimia. $\mathrm{CaSO}_{3}$ yang terbentuk membuat serbuk cangkang kerang menjadi lebih putih.

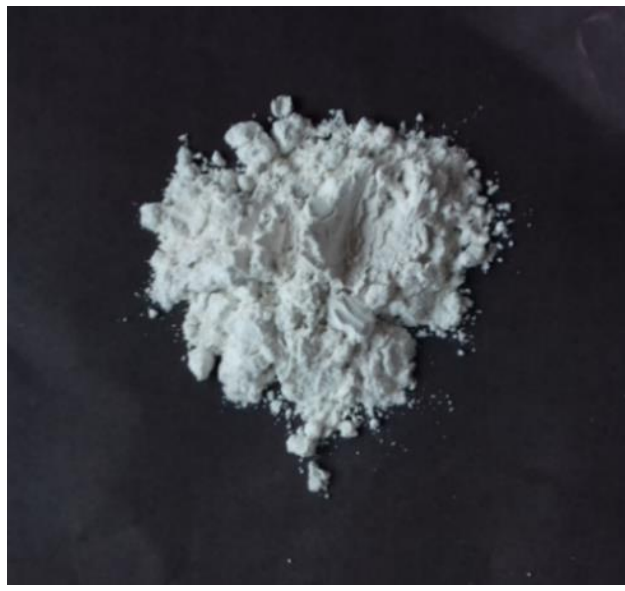

Gambar 5. Serbuk cangkang kerang yang teraktivasi fisika-kimia

\subsection{Karakteristik Air Sumur Bor}

Air uji yang digunakan dalam penelitian ini yaitu air sumur bor yang berlokasi di Kota Baru,
Jl. Perintis, Pontianak, provinsi Kalimantan Barat. Ciri-ciri fisik air uji dalam penelitian ini berwarna kuning kemerahan, keruh, dan bau karat besi. Ciri-ciri air tersebut menandakan adanya kandungan besi yang tinggi pada air sumur bor. Gambar 6 merupakan air sumur bor. Hasil pengujian air sumur bor berdasarkan parameter TDS, warna, kekeruhan, $\mathrm{pH}$, dan Fe dapat dilihat pada tabel 2 .

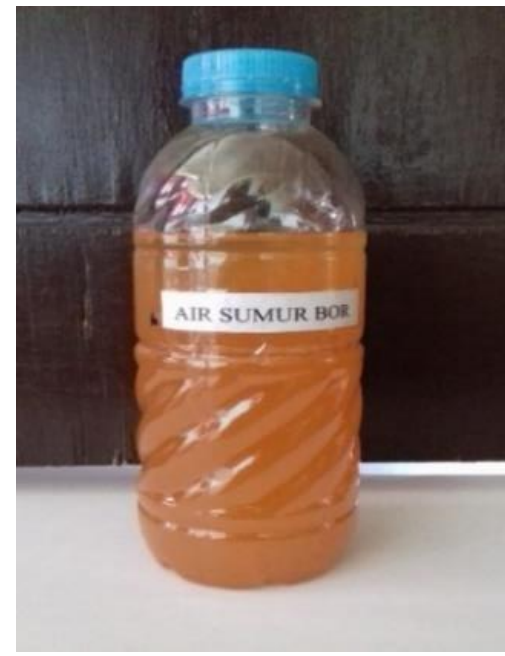

Gambar 6. Sampel air sumur bor

Pada tabel 2 nilai parameter TDS, warna, kekeruhan, $\mathrm{pH}$, dan Fe belum memenuhi syarat yang telah diatur dalam Peraturan Kementerian Kesehatan Republik Indonesia Nomor 32 tahun 2017, yang ditunjukkan pada tabel 1.

\begin{tabular}{|c|c|c|c|}
\hline No & Parameter & Nilai & Satuan \\
\hline 1 & $\mathrm{pH}$ & 4,13 & \\
\hline 2 & TDS & 1461 & $\mathrm{mg} / \mathrm{L}$ \\
\hline 3 & Warna & 1756 & TCU \\
\hline 4 & Kekeruhan & 816 & Pt.Co \\
\hline 5 & Besi (Fe) & 5,98 & $\mathrm{Mg} / \mathrm{L}$ \\
\hline
\end{tabular}

Tabel 3. Hasil pengujian adsorpsi teraktivasi fisika, kimia dan fisika-kimia pada air sumur bor

\begin{tabular}{ccccccc}
\hline \multirow{2}{*}{ Aktivasi } & $\begin{array}{c}\text { Massa } \\
\text { Adsorben } \\
\text { (gram) }\end{array}$ & $\begin{array}{c}\text { TDS } \\
\text { (mg/L) }\end{array}$ & $\begin{array}{c}\text { Warna } \\
(\text { Pt.Co) }\end{array}$ & $\begin{array}{c}\text { Kekeruhan } \\
(\mathrm{NTU})\end{array}$ & $\mathrm{pH}$ & $\begin{array}{c}\text { Fe } \\
(\mathrm{mg} / \mathrm{L})\end{array}$ \\
\hline $\begin{array}{c}\text { Tidak teraktivasi } \\
\text { (Parameter kontrol) }\end{array}$ & 0 & 1461 & 1756 & 816 & 4,13 & 5,98 \\
\hline & 2 & 1488 & 689 & 193 & 6,28 & 0,78 \\
Fisika & 4 & 1492 & 780 & 201 & 6,47 & 0,89 \\
& 6 & 1502 & 818 & 152 & 6,63 & 1,01 \\
& 8 & 1523 & 746 & 126 & 6,79 & 0,90 \\
\hline Kimia & 10 & 1529 & 684 & 144 & 6,84 & 0,82 \\
\hline Fisika-kimia & 10 & 1776 & 406 & 107 & 7,11 & 1,49 \\
\hline
\end{tabular}




\subsection{Analisis Adsorben Teraktivasi Fisika, Aktivasi Kimia, dan Aktivasi Fisika-kimia a. Parameter $\mathrm{pH}$}

Pada Tabel 3, dapat dilihat hasil pengujian air sumur bor setelah ditambahkan adsorben yang teraktivasi fisika, diperoleh nilai $\mathrm{pH}$ pada massa 2 gram dan 4 gram dalam kondisi asam. Hal ini dikarenakan belum terjadi keseimbangan antara sifat asam pada air dengan sifat basa $(\mathrm{CaO})$ dari bahan adsorben. Pada massa 6 gram, 8 gram dan 10 gram untuk adsorben teraktivasi fisika, nilai $\mathrm{pH}$ naik dari keadaan asam ke keadaan netral dikarenakan sifat basa pada serbuk kerang dan sifat asam pada air menjadi seimbang sehingga dapat memenuhi standar baku mutu dan layak untuk digunakan.

$\mathrm{pH}$ air sumur bor yang telah diberikan adsorben cangkang kerang teraktivasi kimia mengalami perubahan dari keadaan asam ke keadaan netral. Hal ini dikarenakan jumlah kation meningkat sehingga menjadikan jumlah $\mathrm{CO}_{2}, \mathrm{H}^{+}$, dan $\mathrm{OH}^{-}$seimbang. $\mathrm{pH}$ air tersebut memenuhi standar baku mutu air pada Tabel 1 sehingga layak digunakan.

Pada proses adsorpsi cangkang kerang setelah ditambahkan adsorben teraktivasi fisikakimia, nilai pH meningkat dari keadaan asam ke keadaan basa. Hal ini disebabkan meningkatnya konsentrasi ion karbonat dan bikarbonat dalam air [14]. Selain itu, sifat basa kuat yang terdapat dalam serbuk cangkang kerang $\left(\mathrm{CaSO}_{3}(\mathrm{OH})_{2}\right)$ juga mempengaruhi nilai pH dari asam menjadi basa.

\section{b. Parameter Fe}

Tabel 3 menunjukkan penurunan kandungan $\mathrm{Fe}$ seiring dengan kenaikan massa adsorben baik yang diaktivasi fisika maupun aktivasi fisika-kimia. Dari hasil uji awal air pada parameter $\mathrm{Fe}$, kandungan $\mathrm{Fe}$ air sumur bor tidak memenuhi standar baku mutu air yang telah ditetapkan pada Tabel 1. Setelah ditambahkan adsorben cangkang kerang darah teraktivasi fisika dengan variasi massa 2 gram, 4 gram, 8 gram dan 10 gram dapat memenuhi standar baku mutu air. Hal ini dikarenakan kandungan Fe yang terlarut dalam air terperangkap ke dalam poripori cangkang kerang sehingga mampu menurunkan kandungan Fe air sumur bor. Sedangkan pada sampel bermassa 6 gram yang teraktivasi fisika belum memenuhi standar baku mutu air. Kemungkinan terjadi kesalahan pada proses pemindahan sampel ke tempat sampel uji. Adsorben teraktivasi fisika mempunyai efektivitas masing-masing sebesar 86,96\%, $85,12 \%, 83,11 \%, 84,95 \%$, dan 86,29\%.

Kandungan Fe pada air sumur bor setelah ditambahkan adsorben teraktivasi kimia, tidak memenuhi standar baku mutu air. Hal ini dikarenakan pemberian massa adsorben dan waktu kontak yang belum tepat. Sampel teraktivasi kimia mempunyai efektivitas sebesar 83,68\%. Adsorben serbuk cangkang kerang yang teraktivasi fisika-kimia dengan massa 10 gram memiliki kemampuan yang lebih baik dibandingkan dengan adsorben yang teraktivasi fisika maupun kimia. Ini dikarenakan pori-pori pada bahan adsorben telah terbuka dan kotoran pada serbuk sudah hilang setelah dilakukan aktivasi kimia. Adsorben teraktivasi fisika mempunyai efektivitas sebesar 99,83\%. Hasil pengujian kandungan $\mathrm{Fe}$ setelah ditambahkan adsorben teraktivasi fisika-kimia telah memenuhi standar baku mutu air pada Tabel 1 sehingga layak untuk digunakan.

\section{c. Parameter Warna}

Telah dilakukan pengujian terhadap air sumur bor menggunakan adsorben teraktivasi fisika dengan massa yang telah ditentukan. Pada tabel 3 menunjukkan adsorben cangkang kerang darah teraktivasi fisika belum memenuhi skala warna pada Tabel 1. Pada proses adsorpsi teraktivasi fisika, zat organik, zat besi atau logam yang terlarut dalam air terperangkap ke dalam pori-pori cangkang kerang. Tidak optimalnya bahan adsorben yang digunakan dikarenakan pori-pori bahan adsorben ditutupi oleh pengotor, serta waktu kontak dan jumlah massa adsorben yang digunakan belum tepat. Efektivitas adsorben teraktivasi fisika dengan variasi massa yang ditentukan sebesar 60,08\%, 55,58\%, $53,42 \%, 57,52 \%$, dan $61,05 \%$. Skala warna air sumur bor yang didapatkan pada Tabel 3 belum memenuhi syarat baku mutu air, sehingga air tersebut tidak layak untuk digunakan.

Pada adsorben teraktivasi kimia, hasil uji yang didapatkan tidak jauh berbeda dengan hasil uji sampel teraktivasi fisika, dikarenakan poripori adsoben kerang darah belum sepenuhnya terbuka sehingga tidak optimal dalam mengadsorpsi unsur-unsur penyebab air berwarna. Efektivitas adsropsi cangkang kerang darah teraktivasi kimia sebesar 73,6 \%. Tabel 3 belum memenuhi syarat baku mutu air, sehingga air tersebut tidak layak utuk digunakan.

Adsorben teraktivasi fisika-kimia dengan massa 10 gram memiliki kemampuan yang lebih baik dibandingkan dengan adsorben teraktivasi fisika dan kimia, dikarenakan pori-pori pada adsorben telah terbuka dan pengotor yang menutupi pori-pori hilang pada saat aktivasi fisika-kimia dilakukan. Efektivitas adsorben teraktivasi fisika-kimia sebesar 97,61 \%. Berdasarkan hasil pengujian pada tabel 3 tersebut, air sumur bor yang telah ditambahkan adsorben teraktivasi fisika-kimia memenuhi 
standar baku mutu air dan air tersebut layak untuk digunakan.

\section{d. Parameter Kekeruhan}

Hasil yang didapat pada tabel 3 menunjukkan kemampuan adsorben teraktivasi fisika cukup baik, tetapi masih belum bisa memenuhi standar baku mutu air pada Tabel 1 . Tidak optimalnya bahan adsorben yang digunakan dikarenakan pori-pori bahan adsorben ditutupi oleh pengotor dan waktu kontak dan jumlah adsorben yang digunakan belum tepat. Adsorben cangkang kerang teraktivasi fisika mempunyai efektivitas masingmasing sebesar 76,35\%, 75,37\%, 81,37\%, $84,56 \%$, dan 82,35\%. Kadar kekeruhan dalam satuan NTU setelah diberi perlakuan aktivasi fisika belum memenuhi syarat baku mutu air, sehingga air tersebut tidak layak untuk digunakan.

Hasil uji nilai kadar kekeruhan pada air setelah diberi adsorben teraktivasi kimia tidak jauh lebih baik dibandingkan dengan adsorben teraktivasi fisika. Hal ini dikarenakan pori-pori adsorben cangkang kerang darah belum sepenuhnya terbuka sehingga kurang maksimal dalam mengadsorpsi unsur-unsur penyebab air menjadi keruh seperti lumpur dan koloid. Efektivitas adsorben cangkang kerang darah teraktivasi kimia sebesar 84,71 \%. Kadar kekeruhan dalam satuan NTU setelah diberi perlakuan aktivasi kimia belum memenuhi syarat baku mutu air, sehingga air tersebut tidak layak untuk digunakan.

Adsorben cangkang kerang teraktivasi fisika-kimia memiliki kemampuan yang lebih baik dibandingkan dengan adsorben teraktivasi fisika maupun kimia. Hal ini dikarenakan poripori pada bahan adsorben telah terbuka dan pengotor yang menutupi pori-pori telah hilang. Efektivitas adsorben cangkang kerang darah teraktivasi fisika-kimia sebesar sebesar 97,61\%. Hasil uji air pada Tabel 3 menunjukkan kadar kekeruhan sudah memenuhi syarat baku mutu air, sehingga air tersebut layak untuk digunakan.

\section{e. Parameter TDS}

Pada Tabel 3 dapat dilihat hasil pengujian air sumur bor setelah ditambahkan adsorben teraktivasi fisika. Hasil pengujian tersebut menunjukkan kenaikan TDS seiring dengan kenaikan massa adsorben baik yang diaktivasi fisika, kimia maupun fisika-kimia. Meningkatnya kadar TDS air disebabkan partikel yang terdapat di dalam bahan adorbsen larut ke dalam air sehingga membentuk koloid. Koloid-koloid yang terlarut dalam air tidak teradsorpsi dengan baik sehingga koloid tersebut tetap terlarut dan meningkatkan kadar TDS air sumur bor [15].
Selain koloid yang terlarut dalam air, oksidasi bahan selama proses adsorpsi juga mengakibatkan naiknya kadar TDS dalam air [16]. Kadar TDS sebelum dan sesudah diberi serbuk cangkang kerang tidak memenuhi standar baku mutu air yang telah ditetapkan.

\section{Kesimpulan}

Karbon aktif yang teraktivasi fisika dengan massa 8 dan 10 gram mampu menurunkan kandungan $\mathrm{Fe}$ dan menaikkan $\mathrm{pH}$ air, sehingga layak untuk digunakan. Karbon aktif cangkang kerang teraktivasi kimia, mampu menaikkan $\mathrm{pH}$ sehingga layak digunakan, tetapi parameter warna, kekeruhan, dan kandungan Fe belum memenuhi baku mutu air. Sedangkan karbon aktif cangkang kerang darah teraktivasi fisikakimia mampu menurunkan kandungan $\mathrm{Fe}$, kadar warna, dan kekeruhan sehingga layak untuk digunakan, tetapi meningkatkan nilai $\mathrm{pH}$ sehingga tidak layak untuk digunakan sebagai air bersih. Adsorben serbuk cangkang kerang untuk semua perlakuan aktivasi tidak efektif digunakan untuk mengadsorpsi TDS.

\section{Daftar Pustaka}

[1] Sunarsih, E.S., Lilo, T., Nugroho, I., dan Sumarni, S., Peningkatan Kualitas Air Bersih dengan Alat Penjernih Air, Jurnal Rural and Development, 4(2), 167-176, 2013.

[2] Jenti, U.B. dan Nurhayati, I., Pengaruh Penggunaan Media Filtrasi Terhadap Kualitas Air Sumur Gali di Kelurahan Tambak Rejo Wani Kabupaten Sidoarjo, Jurnal Teknik Waktu, 12(2), 34-38, 2017.

[3] Bahtiar, A., Pengaruh Suhu Kalsinasi pada Pembuatan Karbon Aktif Kulit Durian Sebagai Adsorben Logam Berat pada Air Sungai, Skripsi, Fakultas MIPA, Universitas Tanjungpura, Pontianak, 2015, (Skripsi).

[4] Asrifah, D., Pengolah Air Backwash Tangki Filtrasi Menggunakan Proses Koagulasi Flokulasi dan Sedimentasi, Jurnal Sains dan Teknologi Lingkungan, 7(1), 29-40, 2015.

[5] Rokayah, Asri, A., Malino, M.B., dan Lapanporo, B.P., Fotodegeradasi Air Sungai Landak dengan Polimer Polipropilena Berfotokatalis Semikonduktor $\mathrm{TiO}_{2}$, Jurnal Positron, 1(1), 13-20, 2019.

[6] Manurung, M., Ivansyah, 0., dan Nurhasanah, Analisis Kualitas Air Sumur Bor di Pontianak Setelah Proses Penjernihan Dengan Metode Aerasi, 
Sedimentasi dan Filtrasi. Prisma fisika, 5(1), 45-50, 2017.

[7] Wiyarsi, A. dan Erfan, P., Pengaruh Konsentrasi Kitosan Dari Cangkang Kerang Terhadap Efesiensi Penjerapan Logam Berat, Tidak diterbitkan, Universitas Negeri Yogyakarta, 2012.

[8] Wahyudianto, F.E., Studi Pemanfaatan Limbah Cangkang Kerang Darah (Anadara Granosa) sebagai Adsorben $\mathrm{Pb}^{2+}, \mathrm{Cu}^{2+}$, dan $\mathrm{Zn}^{2+}$, Fakultas Teknik Sipil dan Perencanaan Institut Teknologi Sepuluh November, Surabaya, 2016, (Tesis).

[9] Apranita, G., Anita, S., dan Hanifah, T.A., Potensi Abu Cangkang Kerang Darah (Anadara Granosa) sebagai Adsorben Ion Timah Putih, Tidak diterbitkan, Universitas Binawidaya Pekanbaru, 2012.

[10] Khan, A. Aida, Efektivitas Pemanfaatan Limbah Cangkang Kerang Darah (Anadara Granosa) Sebagai Media Adsorben Logam $\mathrm{Cu}$ (II) dalam Air, Tidak diterbitkan. Universitas Indonesia, 2016.

[11] Firmansyah, I., Gambaran Histopatologik Tulang Femur Tikus Putih (Rattus norvegicus) Pasca Ovariohisterektomi dengan Suplemen Kalsium Karbonat Dosis Tinggi, Universitas Airlangga, Fakultas Kedokteran Hewan, Surabaya, 2005, (Skripsi).

[12] Peraturan Menteri Kesehatan Republik Indonesia Nomor 32 Tahun 2017 tentang Standar Baku Mutu Kesehatan Lingkungan dan Persyaratan Kesehatan untuk Keperluan Higiene Sanitasi, Kolam Renang, Solus Per Aqua, dan Pemandian Umum. Menteri Kesehatan Republik Indonesia.

[13] Setiadji, S., Nila, T.B., Tety, S., Eko, P.H., dan Bebeh, W.N., Alternatif Pembuatan Biodisel Melalui Transesterifikasi Minyak Castor (Ricinus Communis) Menggunakan Katalis Campuran Cangkang Telur Ayam dan Kaolin, Jurnal Kimia Valensi, 3(1), 110, 2017.

[14] Yuliandini, A., Pengaruh Formasi Batuan Terhadap Karakteristik Hidrokimia Lima Sumber Mata Air Panas Di Daerah Sapan, Pinang Awan, Kecamatan Alam Pauah Duo, Kabupaten Solok Selatan, Jurnal Fisika Unand, 2(4), 212-219, 2013.

[15] Rahmawati, Wilaksono, A., Amri, N., Davidson, N.K., Rimawan, B., dan Heriyanti, Adsorpsi Air Gambut
Menggunakan Karbon Aktif Dari Buah Bintaro, Chempublish Journal, 2(2), 14-20, 2018.

[16] Salim, N., Rizal, N.S. dan Vihantara, R., Komposisi Efektif Batok Kelapa sebagai Karbon Aktif Untuk Meningkatkan Kualitas Air Tanah di Kawasan Perkotaan, Jurnal Media Komunikasi Teknik Sipil, 24(1), 217-226, 2018. 